\title{
芦屋市をモデルとした兵庫県南部地震による建物被害評価の変換法 CONVERSION OF FRAGILITY CURVES FOR BUILDINGS IN ASHIYA CITY DUE TO THE 1995 HYOGOKEN-NANBU EARTHQUAKE
}

\author{
村尾 修*, 山崎文雄**, 目黒公郎** \\ Osamu MURAO, Fumio YAMAZAKI and Kimiro MEGURO
}

\begin{abstract}
A number of building damage surveys were carried out for different purposes after the 1995 Hyogoken-Nanbu Earthquake. The damage surveys by local governments intended its use for property tax reduction while the survey by the AIJ \& CPIJ group, academic societies, aimed to get technical records. This paper compares these building damage data in Ashiya City, using estimated peak ground velocity and fragility curves. The purpose of this study is to clarify the relationship between the two evaluations. The result obtained could be used to convert the damage rank by local governments to that by the AIJ \& CPIJ group.
\end{abstract}

Keywords: the Hyogoken-Nanbu Earthquake, building damage evaluation, strong ground motion, Ashiya City, fragility curve, GIS

兵庫県南部地震, 建物被害評価, 地震動, 芦屋市, 被害推定式, 地理情報システム

1. はじめに

地震による建物被害の程度を表すひとつの尺度として「全壊率」 や「全半壊率」が用いられることが多い。それらは今後の防災にお ける貴重な記録としてだけではなく，被害推定式の重要なパラメー 夕として被害想定等にも使われる。しかし一口に「全壊」，「半壊」

と言っても，その定義は調査によって異なっており，それらを使用 する際には注意が必要である1).

1995 年 1 月に発生した兵庫県南部地震では, 全壊約 11 万棟, 半 壊約 14 万 7 千棟)という多大な住家被害を受けた. 被災地ではそ れぞれ異なる目的でいくつかの建物被害調査 ${ }^{11}$ が実施されたが, 方法および判定基準はそ扎ぞ異なっており，判定結果に大きな影 響を与えていたと思われる゙. 本研究ではその中から，自治体によ る減免および義援金補助のための「家屋被害調査」と，日本都市計 画学会関西支部および日本建築学会近畿支部都市計画部会を中心之 して構成された震災復興都市づくり特別委員会（以下「震特委員 会」）による被災記録のための「被害実態緊急調查3). 4)」を取り上 げ，比較分析を行った．前者は被災者救済のために政府の通達（内 閣官房審議室 1968 「被害認定統一基準」）に基づき，国から義務づ けられているもので大地震時には必ず実施されるが, 家屋の資産的 価値の損失度を見積もることが主たる目的であるため，実際の建物 の被害評価という点では緩い基準となっている.一方後者は, 阪神・ 淡路大震災の全体像の把握と今後への学術的貢献を目的として実施 された調查である. 主に建物が再使用可能かどうかという視点から
建物被害評価を行っており，建築工学・土木工学・都市計画に関わ る専門家とそれらの分野を専攻する学生等によって実施されている ため，都市防災という観点からすると大変貴重な資料である．被災 地域の地震動の面的分布推定には, 翠川ら5)のように墓石転倒調査 から求めることができるが, 広域にわたって同一の基準で判定され ているこの建物被害調查を用いて求めることも可能である6). しか し，このような調査が今後の大地震時に必ず行われるという保証は ない. したがって各自治体によって今後も確実に実施されるであろ う「家屋被害調査（建築年・構造等を含む詳細データ）」から, 兵 庫県南部地震時に震特委員会等が行ったような建物被害判定に変換 する評価式を構築しておくことは, 今後フラジリティカーブの作成 や防災的な都市計画を進めるうえで大いに役立つと思われる.

本研究では上で述べた評価変換式の構築を目的として, 芦屋市に おける特定地域の一棟一棟の建物を対象として, 自治体と震特委員 会による建物被害調査の判定結果を比較し, さらに推定される地震 動との関係を分析している.

\section{2. 芦屋市における建物被害判定結果の比較 \\ (1) 建物被害調査の概要}

以下に本研究で対象とした建物被害調査の概要を示す.

被災者に対する義援金の配分および固定資産税の減免措置は，各 自治体によって実施される「家屋被害調查」の判定結果によって行 われる. 芦屋市では「被害認定統一基準」に基づき作成された独自
* 東京大学生産技術研究所 助手・王修

** 東京大学生産技術研究所 助教授. 一博
Research Assoc., Institute of Industrial Science, University of Tokyo, M. Eng. Assoc. Prof., Institute of Industrial Science, University of Tokyo, Dr. Eng. 
の被害調査票をもとに，数回にわたる調查を実施した7).

一方, 震特委員会による被害実態緊急調査 ${ }^{3}$ は, 日本都市計画学 会学術委員会と日本建築学会都市計画委員会の間で，淡路島から阪 神地域数十キロメートルに及ぶ市街地の，建築物被災の全体像を客 観的にデータ化することを目的として実施された，構造種別は明ら かでないが, 阪神地域というかなり広い範囲での調査である. 判定 基準は修理・再利用可能性の観点から設定されており，建物の被災 度評価は，外観の目視により，ランク $\mathrm{C}$ : 全壊または大破（以下「大 破」), ランク B：中程度の損傷（以下「中破」）, ランク A：軽微な 損傷（以下「軽微」），無被害の4段階で評価している.

表 1に芦屋市と震特委員会による調查内容の比較を示す。芦屋 市の調査は建物の資産的価値の損失度を見積もるという側面も含ま れているため, 建物内部の床・階段・建具・設備等も評価対象とな つているのに対し, 震特委員会の方は目視による外観調査であるた め, 建物内部は調査対象から外れている。

筆者らの研究グループはこれまでに兵庫県南部地震における建 物被害分析を行ってきたが, ほとんどの地域で自治体の方が震特委 員会の判定基準よりも緩くなっている8)-13).

表 2, 図 1に芦屋市における自治体と震特委員会による調査の 建物被害棟数と被害率4).89の比較を示す．ただし両調查には，目的， 調査地域, 対象建物等に違いがあるため, 合計棟数は異なっている. この結果から，概して芦屋市の全壊は震特委員会の中破以上, 芦屋 市の全半壊は震特委員会の軽微以上とほぼ等しいと仮定できる. 本 研究で一棟一棟の判定結果を比較することにより, より詳細な傾向 を見いだすことが可能であろう。

(2) 研究の方法

研究を進めるにあたり，芦屋市内で被害の大きかった住宅地区を 15 のエリアに区分し，分析対象地域とした（図 2). 各エリアの建 物棟数と町名を表 3 に示す。この中で臨海部にある.N，Oの 2 エリ ア（芦屋浜）は地震動よりも液状化による被害が多発した地域であ り，また高層集合住宅が多いために比較的木造建物比が小さく，他 エリアとは異なった特性を持っている. 以上の 15 エリアについて, 芦屋市による建物被害状況図”之震特委員会による被災度別建物分 布状況図勇を見比べ，対応のついた 12,138 棟の建物の被害判定結果 (1:2)を比較し，エリアごとの分析を行った。

（3）エリアごとの建物被害判定結果の比較

対象地域全域での判定結果と芦屋市による建物被害判定に占める 震特委員会判定の比率を表 4, 図 3に示す. 全壊判定の中では大破 が，半壊判定の中では軽微が，その他判定の中では無被害がそれぞ れ 63\%，47\%，77\%を占めている. また全壊判定の中に無被害が 4.5\%, その他判定の中に大破が $0.6 \%$ と正反対の判定も含まれていた.

建物被害調査の判定結果を GIS 上に表示し，比較したものを図 4 に示す．液状化の激しかった臨海 2 エリアを除き，全体的に震特委 員会の中破以上が芦屋市の全壊判定に近く，また軽微以上が全半壊 判定に近い傾向を見せている.

図 5は芦屋市による建物被害判定ごとの震特委員会判定の内訳で ある.全壇と判定された建物の中には大破の判定が多く見られるが, 特に震度 7 の帯（図 2）の中でその傾向が特に高い. 臨海 2 エリア の内エリア Nでは全壊棟数が 0 であり，エリア $\mathrm{O}$ では芦屋市によ り全壊と判定されていた建物が軽微な損傷とされているのがわかる. また芦屋市によりその他と判定された建物の大半は無被害と判定さ 扎ており, 震度 7の帯から離れたエリアでその傾向が高くなってい
る. 以上のことから芦屋市による判定と震特委員会による判定の対 応は地震動の強さとも関係がありそうである.

半壊判定は主に中破と軽微な損傷によって占められているが, 全 壊とその他の中間に位置するためか，その内訳が場所によって大き く異なっている.

図 6计芦屋市の全壊判定と震特委員会の中破以上の判定（大破+ 中破）をエリアごとの率でプロットしたものである，線形近似をと ったところ全 15 エリアでは $\mathrm{R}^{2}=0.98$, 臨海 2 エリアを除いた場合

\section{表 1 建物被害調査内容の比較}

\begin{tabular}{|c|c|c|}
\hline & 芦屋市 & 震特委員会 \\
\hline 調查方法 & $\begin{array}{l}\text { 消防本部毗員が目視により椇害度 } \\
\text { 合を調べ判定 }\end{array}$ & 専門家・学生等による外観目視 \\
\hline 調查員 & $\begin{array}{l}\text { 消防本部部買 } \\
\text { 再調査は専門家の協力有（3人1 } \\
\text { 組) }\end{array}$ & $\begin{array}{l}\text { 建築工学・土木工学・都市計画に } \\
\text { 関わる尃門家・学生等 }\end{array}$ \\
\hline 調查期間- & $\begin{array}{l}1 / 23-1 / 29 \\
2 / 4-2 / 10 \\
3 / 17-3 / 21\end{array}$ & $\begin{array}{l}2 / 1-2 / 9 \\
2 / 10-3 / 13\end{array}$ \\
\hline 評価方法 & 独自の調查票による百分率評価 & $\begin{array}{l}\text { 調查票の定義 (構造別) に従って } \\
\text { 判定 }\end{array}$ \\
\hline \begin{tabular}{|l|} 
被多度評価 \\
判定定義
\end{tabular} & 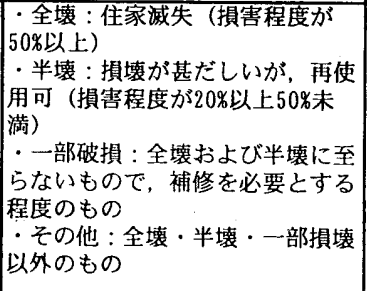 & 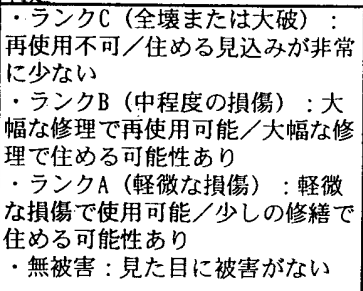 \\
\hline $\begin{array}{l}\text { 木造 } \\
\text { 調查項目 }\end{array}$ & $\begin{array}{l}\text { 全体傾斜／屋根（天井）/壁（外 } \\
\text { 壁・内壁）／基礎・床／柱／階段 } \\
/ \text { その他 }\end{array}$ & 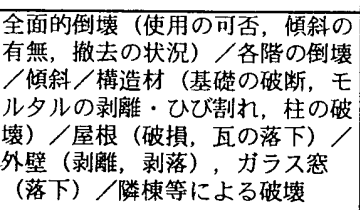 \\
\hline $\begin{array}{l}\text { 韭木造 } \\
\text { 調查項目 }\end{array}$ & $\begin{array}{l}\text { 全体傾斜/柱/梁/耐震壁/基礎 } \\
\text { /外部雑壁/階段/内部壁・仕上 } \\
\text { ／建具／天井／床／設備／その他 }\end{array}$ & $\begin{array}{l}\text { 各跸の倒壊/傾斜/構造材（基礎 } \\
\text { の破断, 柱梁の破壊・座屈, 柱脚 } \\
\text { アン力-の破断, 沈下)／外壁 } \\
\text { (剥離, 剥落) }\end{array}$ \\
\hline
\end{tabular}

表 2 建物被害棟数の比較

\begin{tabular}{|l|r|r|r|r|r|}
\hline 判定主体 & $\begin{array}{c}\text { 全壊 } \\
\text { 大破 (C) }\end{array}$ & $\begin{array}{c}\text { 半壊 } \\
\text { 中破 (B) }\end{array}$ & $\begin{array}{c}\text { 一部損罗 } \\
\text { 軽微 (A) }\end{array}$ & $\begin{array}{c}\text { その他 } \\
\text { 無被害 }\end{array}$ & 合計 \\
\hline 芦屋市 & 4,797 & 4,222 & 4,780 & 1,979 & 15,778 \\
\hline 震特委員会 & 2,932 & 1,558 & 3,438 & 5,681 & 13,609 \\
\hline
\end{tabular}

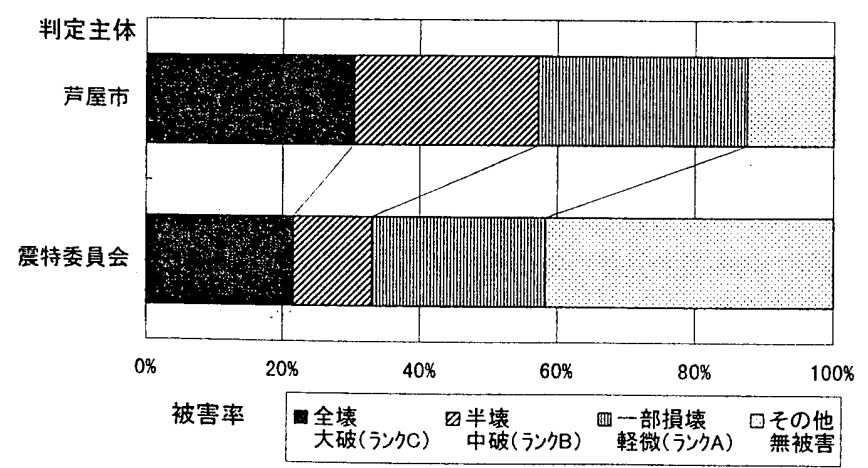

図 1 建物被害率の比較 
は 0.97 という高い相関が見られ，共に傾きは 1.09 となった.

次に芦屋市による全半壊の判定と震特委員会による軽微以上の判 定の比較を図 7に示す.まず全 15 エリアについて回帰したところ, 点線で示した近似直線のようになり， $\mathrm{R}^{2}=0.22$ と相関が著しく低く なったため，木造率が低く液状化の激しかった臨海 2 エリアを除外 して再度回帰した. その結果, $\mathrm{R}^{2}=0.80$ まで上がり, 傾きは 1.03 と なった。臨海 2 エリアのように木造が少ない地域では，建物自体の

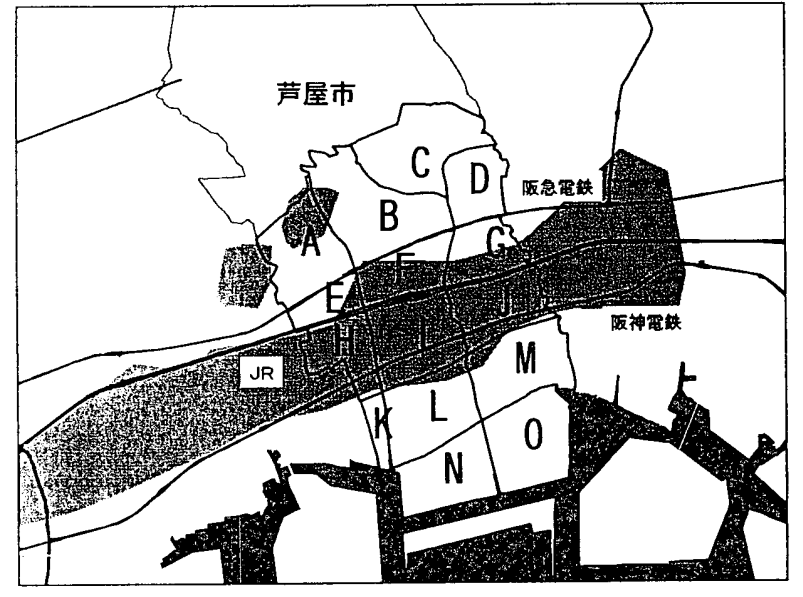

図 2 芦屋市対象地域と震度 7 の帯

表 3 エリアごとの建物棟数と町名

\begin{tabular}{|c|c|c|}
\hline II) & 建物棟数 & 町名 \\
\hline $\mathrm{A}$ & 941 & 三条町·山芦屋町・西山町 \\
\hline $\mathrm{B}$ & 1,208 & 山手町・東芦屋町・東山町 \\
\hline C & 830 & 朝日ヶ丘町・六麓荘町 \\
\hline D & 604 & 岩園町 \\
\hline $\mathrm{E}$ & 537 & 三条南町・西芦屋町・月若町 \\
\hline $\bar{F}$ & 812 & 松八内町・船戸町・大原町 \\
\hline$G$ & 800 & 親王冢町・翠ヶ丘町 \\
\hline $\mathrm{H}$ & 733 & 清水町 - 前田町 - 津知町 - 川西町 - 平田北町 \\
\hline I & 1,401 & $\begin{array}{l}\text { 業平町 - 公光町 - 大桝町 - 茶屋之町 - 精道町 } \\
\text { - 上宫川町 - 宮塚町 - 宮川町 }\end{array}$ \\
\hline 1 & 1,080 & 楠町 - 打出小棺町 - 春日町 - 若宮町 - 打出町 \\
\hline K & 142 & 平田町 \\
\hline $\bar{L}$ & 1,060 & 浜芦屋町・松浜町 - 伊勢町 - 竹園町 - 吳川町 \\
\hline$M$ & 1,014 & 西藏町・浜町・南宮町・大東町 \\
\hline $\bar{N}$ & 493 & 緑町・潮見町・若葉町 \\
\hline 0 & 483 & 高浜町 $\cdot$ 新浜町 $\cdot$ 浜風町 \\
\hline
\end{tabular}
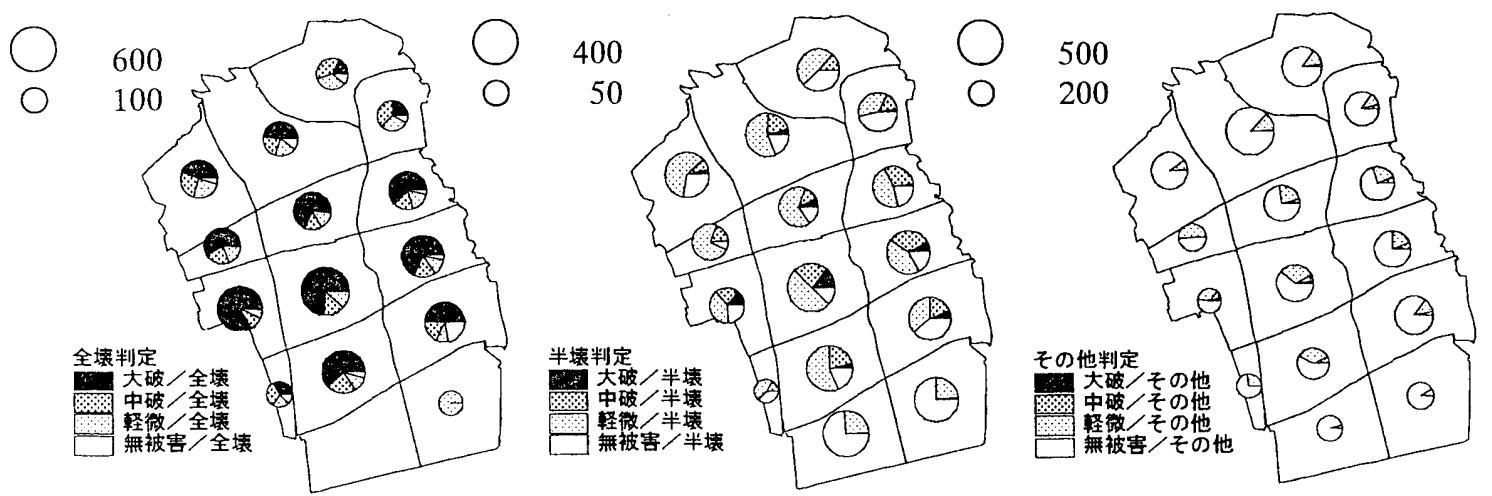

（円の大きさはエリアごとの棟数を示す）
被害が小さく，家具の転倒等により内部被害は大きいという事態が 発生する. したがって, 外観目視による震特委員会の判定と, 内部 評価を含んだ自治体の判定が大きく異なることが考えられる. 図 6 と図 7の中で, 臨海 2 エリアによる影響に違いが見られたのは，こ

表 4 対象地域全域における建物被害判定結果

\begin{tabular}{|c|c|c|c|c|c|c|}
\hline & \multicolumn{5}{|c|}{ 震災復興都市づくり特別委員会 } \\
\hline & & 大破 & 中破 & 軽微 & 無被害 & 合計 \\
\hline 芦 & 全壊 & 2,150 & 624 & 481 & 153 & 3,408 \\
\hline 屋 & 半壊 & 186 & 654 & 1,861 & 1,296 & 3,997 \\
\hline 市 & その他 & 28 & 145 & 896 & 3,664 & 4,733 \\
\hline & & 364 & 1,423 & 3,238 & 5,113 & 12,138 \\
\hline
\end{tabular}

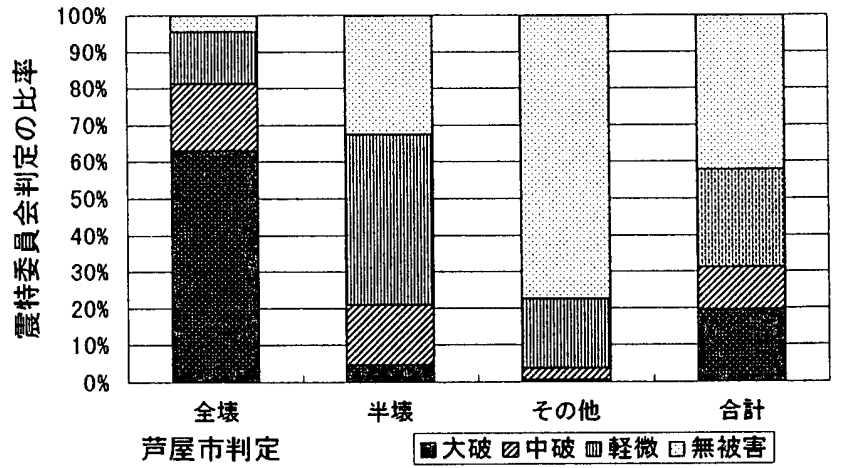

図 3 芦屋市による建物被害判定に占める震特委員会判定の比率

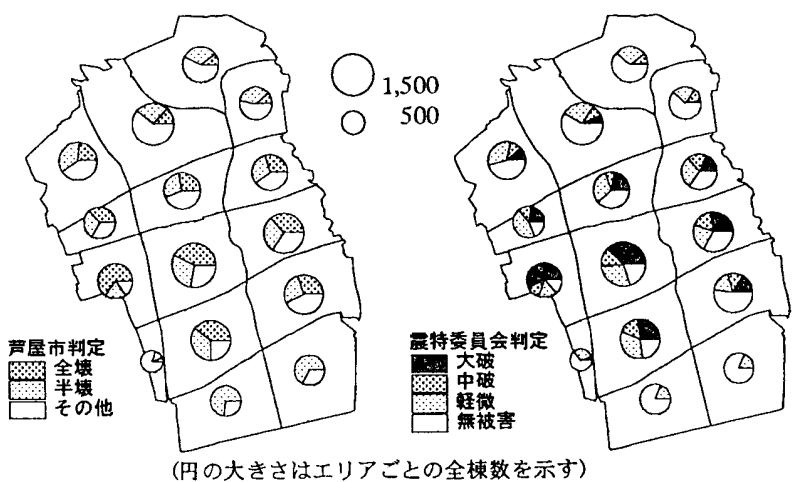

図 4 エリアごとの建物被害判定結果の比較

図 5 芦屋市による建物被害判定ごとの震特委員会判定の内訳 
のような理由からであろう.

以上のことから, 全体としてとらえた場合, 芦屋市の全壊判定は 震特委員会の中破以上とほぼ等しく, また臨海 2 エリアを除いたほ とんどのエリアで芦屋市の全半壊判定は震特委員会の軽微な損傷以 上とほぼ等しいということが言える.

\section{3. 建物被害判定ごとの被害率曲線の比較と評価変換}

前章で, 芦屋市による判定と震特委員会による判定の対応関係は 地震動の強さに関倸しているらしいことを述べた．ここでは低層建 物の被害と地震動観測值から推定された兵庫県南部地震の地震動分 布を用いて，建物被害推定式（フラジリティカーブ）を求め, 地震 動の最大速度と建物被害判定の関係を調べた.

(1) 対応レベルの設定

まず芦屋市と震特委員会判定の対応関係を調べる. 前章の結果か ら「芦屋市の全壊は震特委員会の中破以上と等しい」,「芦屋市の全 半壊は震特委員会の軽微な損傷以上と等しい」と仮定し, 芦屋市と 震特委員会の判定の関係を以下のように 4 つのレベルに設定した.

Level 1 : 仮定どおり芦屋市の判定基準の方が緩いもの

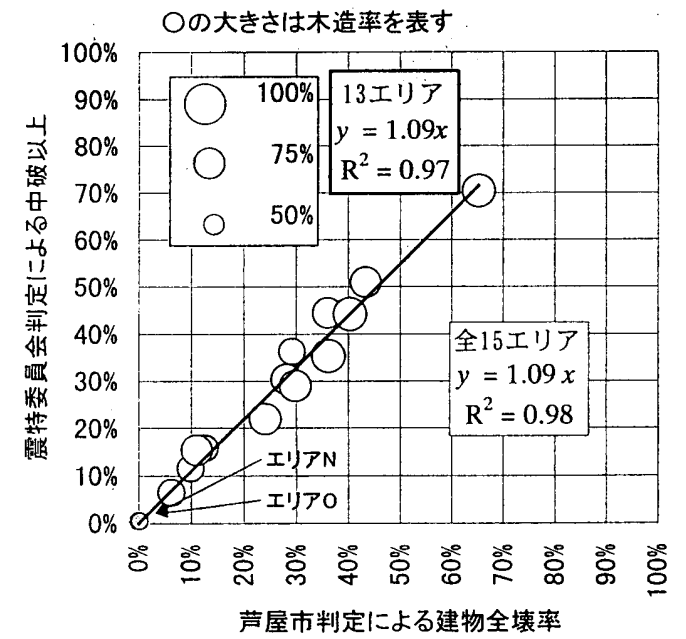

図 6 エリアごとの判定比較 I

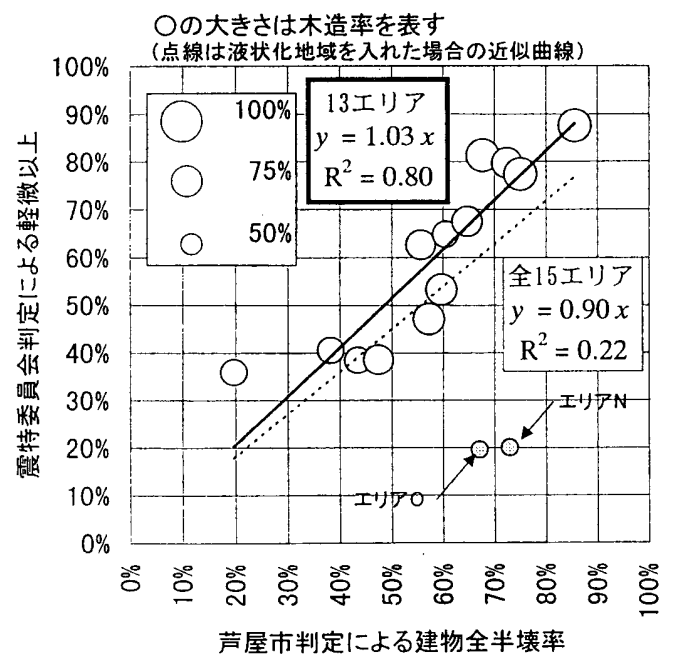

図 7 エリアごとの判定比較 II
Level 2 : 仮定以上に芦屋市の判定基準の方が緩いもの Level 3 : 仮定と逆になっているもので Level 4 以外のもの

Level 4 :「全壊と無被害」,「その他と大破」のように正反対の 判定が出てしまっているもの

対応レベルの内容とその棟数およびエリアごとの比率を図 8に示 す. 芦屋市の判定基準の方が緩くなっている Level 1 と Level 2 は 全体の 95.8\%と大半を占めている. また Level 3, Level 4 は, それ ぞれ 2.7\%，1.5\%と少なかった. Level 3, Level 4 のような対応関 係は調查項目に室内の被害が含まれるか否かという2 調査の差から 発生すると考えられる. さらに Level 4 のように正反対の判定が出 てしまった理由としては, 調查時に使用した地図の違いによる建物 の誤認，地図にプロットする際の写し間違いなどから発生する両調 査記録の不一致なども考えられる.エリアごとの対応レベルの比率 を見ると臨海 2 エリアで他エリアと違う傾向が見られ， Level 1 と Level 2 が半分ずつで, Level 3, Level 4 は存在しなかった. その理 由として液状化現象による被害, 木造比の少なさ等が考えられるが, ここでは判断できない.

(2) 建物被害推定式

筆者らの研究グループは, 兵庫県南部地震時に得られた強震記録 と, 震特委員会および兵庫県都市住宅部計画課が行った建築物被災 度調査結果を建設省建眐研究所が数值化したデータ4)を用いて, 被 害推定式を作成し，阪神地域の地震動の空間分布を推定した ${ }^{14)}$. た だし，この検討で用いた建物デー夕は構造種別や建築年代の属性が 含まれていないため，木造戸建にほほ相当すると思われる低層戸建 住宅のデー夕を用いた。本研究では，ここで得られた芦屋市内の推 定地震動（町丁目単位の最大速度）を用いて, 芦屋市と震特委員会 の実施した 2 調査に基づく全建物に関する建物被害推定式の構築を 試みた．ただしこの地震動デー夕は町丁目を単位としているため, 全棟数による重み付き平均により対象エリアごとの地震動に換算し た. また対象エリアは臨海 2 エリアを除いた 13 エリアとしている.

ここで求めた地震動強さ（最大速度）と被害率の関係から, 調査 ごとの建物被害推定式を求める. 算出した推定地震動強さ（最大速 度）と建物被害率を表 5 に示す。 ある地震動 $x$ のときに被災ランク $\mathrm{R}$ 以上の被害が発生する確率 $P_{R}(x)$ は，標準正規分布の累積確率分 布関数 $\Phi(x)$ を用いて, 対数正規分布で表せると仮定した. すなわち,
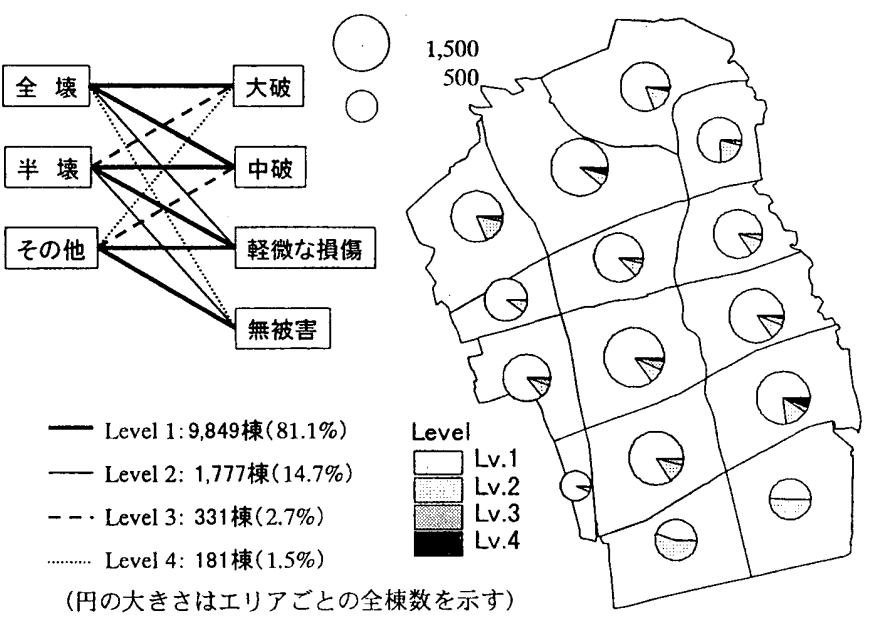

図 8 被害判定の対応レベルとエリアごとの比率 


$$
P_{R}(P G V)=\Phi((\ln P G V-\lambda) / \zeta)
$$

となる.ここで係数 $\lambda, \zeta は, ~ \ln P G V$ の平均值および標準偏差であ り，図 9, 図10に示すような確率紙を用いた最小二乗法により求 めた．その結果を表 6に示す. また各被害推定式を図 11 (芦屋市), 図 12（震特委員会）に示す. 図 13は芦屋市と震特委員会のそれぞ れの建物被害推定式を重ねて比較したものである. 芦屋の判定は曲 線を用いて，震特委員会の各判定は領域を用いて表現している．た だし，最大速度は，再現地震動の最大速度値から， $50 \sim 150 \mathrm{~cm} / \mathrm{s}$ 程 度までが適用範囲であると考えられる。

\section{表 5 建物被害推定式の構築に用いた推定地震動と建物被害率}

\begin{tabular}{|c|c|c|c|c|c|c|c|}
\hline \multirow[t]{2}{*}{ I⿰丬士⿻尸 } & \multirow{2}{*}{$\begin{array}{c}P G V \\
(\mathrm{~cm} / \mathrm{s})\end{array}$} & \multirow{2}{*}{$\begin{array}{c}\text { 建物棟数 } \\
\text { （棟） }\end{array}$} & \multicolumn{2}{|c|}{ 芦屋市調査 } & \multicolumn{3}{|c|}{ 震特委員会調査 } \\
\hline & & & 全壊率 & 全半壊率 & 大破 & 中破以上 & 軽微以 \\
\hline A & 84.2 & 941 & $24.2 \%$ & $59.7 \%$ & $12.1 \%$ & 21.88 & $53.1 \%$ \\
\hline$B$ & 76.2 & 1,208 & $12.7 \%$ & $38.3 \%$ & $7.2 \%$ & 15.78 & $40.5 \%$ \\
\hline $\mathrm{C}$ & 63.6 & 830 & $10.0 \%$ & $43.5 \%$ & 2.0\% & $11.4 \%$ & $38.4 \%$ \\
\hline D & 66.0 & 604 & $11.1 \%$ & $47.5 \%$ & $3.5 \%$ & $5.2 \%$ & $38.4 \%$ \\
\hline $\mathrm{E}$ & 95.7 & 537 & $36.3 \%$ & $67.8 \%$ & $21.8 \%$ & $5.2 \%$ & $31.2 \%$ \\
\hline F & 99.7 & 812 & $28.2 \%$ & $55.8 \%$ & $21.8 \%$ & $0.3 \%$ & $32.6 \%$ \\
\hline G & 100.0 & 800 & 29.38 & $60.5 \%$ & $19.1 \%$ & $6.1 \%$ & $54.8 \%$ \\
\hline $\mathrm{H}$ & 177.4 & 733 & $65.3 \%$ & $85.7 \%$ & $57.3 \%$ & $70.3 \%$ & $87.4 \%$ \\
\hline$I$ & 122.0 & 1,401 & $43.4 \%$ & $72.4 \%$ & $36.5 \%$ & $50.9 \%$ & $79.7 \%$ \\
\hline $\mathrm{J}$ & 111.2 & 1,080 & $36.1 \%$ & $64.7 \%$ & $27.0 \%$ & $44.4 \%$ & $67.4 \%$ \\
\hline $\mathrm{K}$ & 62.7 & 142 & 6.38 & $19.7 \%$ & $2.1 \%$ & $6.3 \%$ & $35.9 \%$ \\
\hline L & 100. & 1,060 & 40.48 & $75.1 \%$ & $26.7 \%$ & $44.2 \%$ & 77.38 \\
\hline & 97.0 & 1,014 & $30.0 \%$ & $57.3 \%$ & $16.6 \%$ & $28.9 \%$ & $46.9 \%$ \\
\hline
\end{tabular}

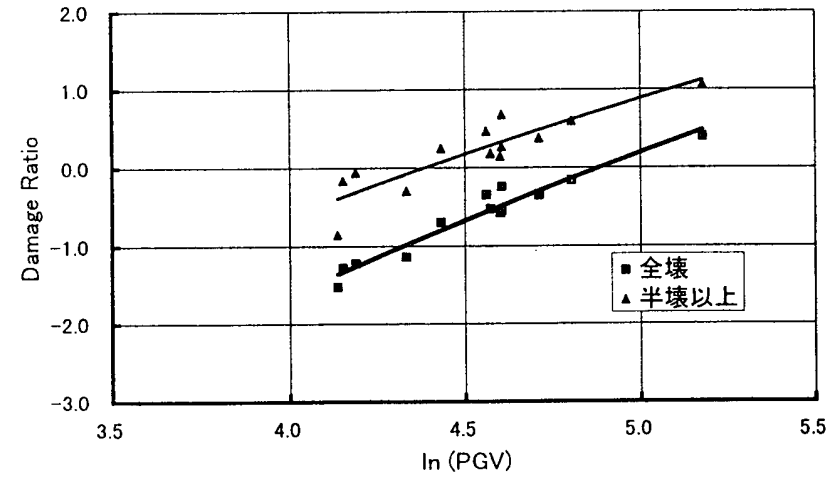

図 9 最大速度と芦屋市による建物被害率の関係の確率紙表示

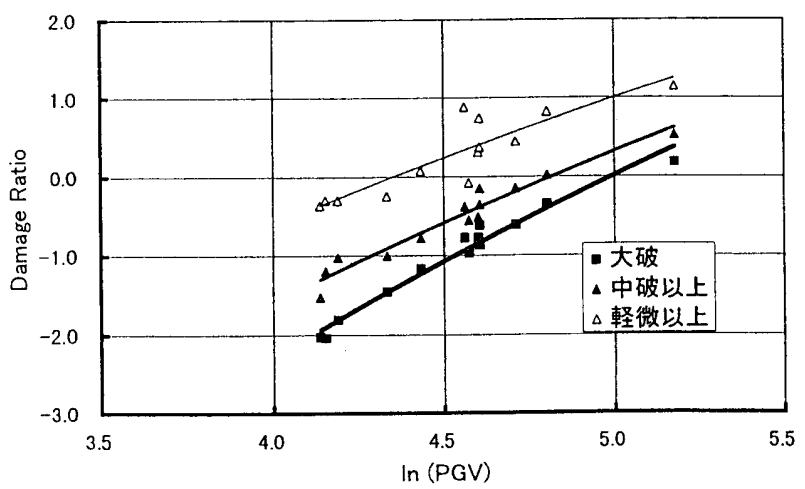

図 10 最大速度と震特委員会による建物被害率の関係の確率紙表示
この図から芦屋市判定（全壊, 半壊）と震特委員会判定（大破, 中破, 軽微) の関係を見ると, 大破の発生確率は地震動の大きさに 関わらず, 全壊の発生確率より小さくなっている. 中破以上の発生

表 6 建物被害予測式の係数

\begin{tabular}{|l|c|c|c|}
\hline 芦屋市ランク & $\lambda$ & $\zeta$ & $\mathrm{R}^{2}$ \\
\hline 全壞 & 4.88 & 0.559 & 0.94 \\
\hline 半壊以上 & 4.39 & 0.680 & 0.78 \\
\hline \hline 震特委員会ランク & $\lambda$ & $\zeta$ & $\mathrm{R}^{2}$ \\
\hline 大破 & 4.98 & 0.444 & 0.96 \\
\hline 中破以上 & 4.83 & 0.535 & 0.94 \\
\hline 軽微以上 & 4.34 & 0.637 & 0.78 \\
\hline
\end{tabular}

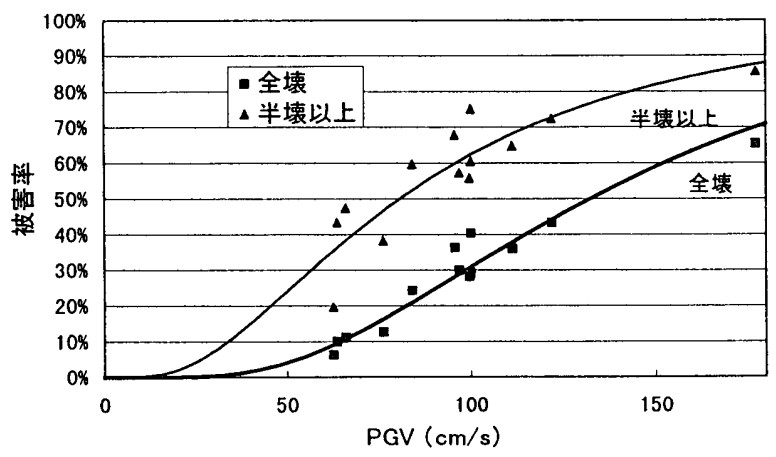

図 11 芦屋市データに基づく建物被害推定式

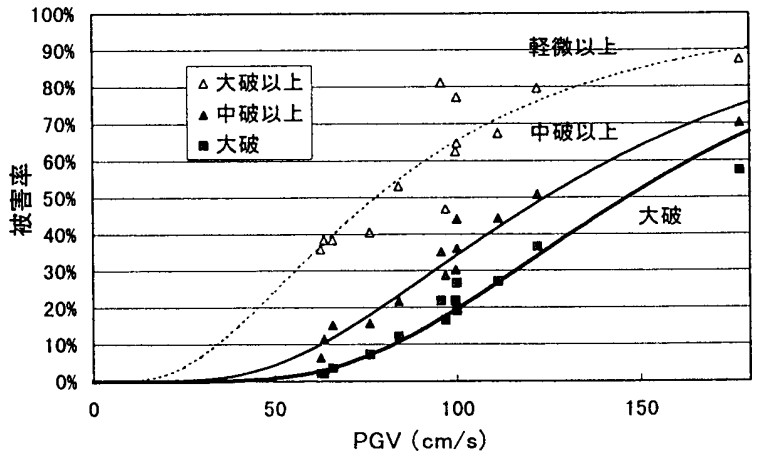

図 12 震特委員会データに基づく建物被害推定式

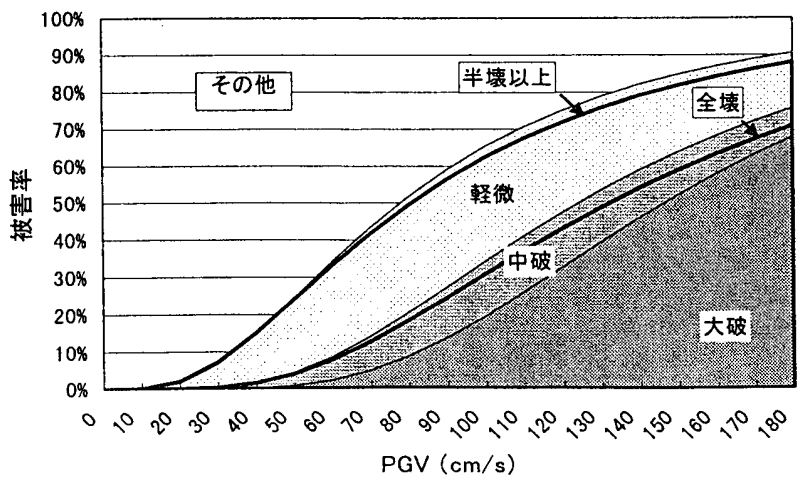

図 13 芦屋市と震特委員会の建物被害推定式の比較 
確率は約 $60 \mathrm{~cm} / \mathrm{s}$ 以下で全壊の発生確率とほぼ等しいが，地震動が 大きくなるにしたがい，全壊判定よりも大きな発生確率となってい る.また軽微以上の発生確率も. $60 \mathrm{~cm} / \mathrm{s}$. 以下で全半壊のものとほぼ 等しいが，地震動が大きくなるにつれ，全半壊判定よりも大きな発 生確率となっている.

\section{（3）建物被害推定式による比較と評価率}

前節では建物被害推定式を構築することにより，芦屋市と震特委 員会における各判定ごとの関倸を調べた。しかし実際には図 130 ように大破の判定が全て全壊と判定されているわけではない，そこ で芦屋市判定のフラジリティカーブを固定して；その内訳を調べた.

ここでは前節と同様に図14に示すような確率紙を用いた最小二 乗法により求めている. 表 7 判定ごとの in $P G V$ の平均値 (

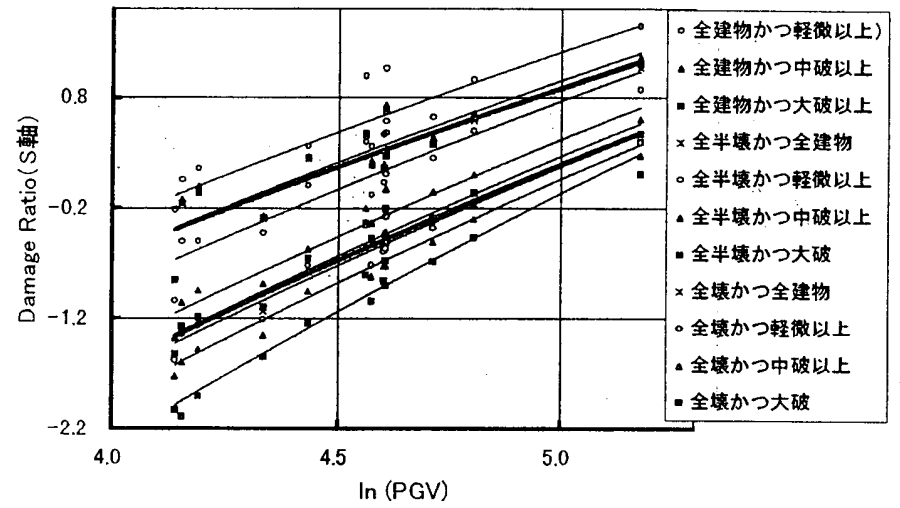

図 14 最大速度と各建物被害率の関係の確率紙表示

\section{表，7．各判定ごとの建物被害予測式の倸数}

\begin{tabular}{|c|c|c|c|c|}
\hline 芦屋市ランク & 震特委員会ランク & $\lambda$ & $\zeta$ & $\mathrm{R}^{2}$ \\
\hline \multirow[t]{4}{*}{ 全壊 } & 天破 & 5.05 & 0.455 & 0.96 \\
\hline & 中破以上 & 4.95 & 0.515 & 0.95 \\
\hline & 軽微以上 & 4.90 & 0.543 & 0.93 \\
\hline & 全建物 & 4.88 & 0.559 & 0.94 \\
\hline \multirow[t]{4}{*}{ 半壊以上 } & 大破 & 4.84 & 0.538 & 0.94 \\
\hline & 中破以上 & 4.76 & 0.552 & 0.94 \\
\hline & 軽微以上 & 4.52 & 0.606 & 0.84 \\
\hline & 全建物 & 4.39 & 0.680 & 0.78 \\
\hline \multirow[t]{4}{*}{ その他以上 } & 大破 & 4.40 & 0.671 & 0.78 \\
\hline & 中破以上 & 4.38 & 0.654 & 0.78 \\
\hline & 軽微以上 & 4.17 & 0.667 & 0.78 \\
\hline & 全建物 & - & - & - \\
\hline
\end{tabular}

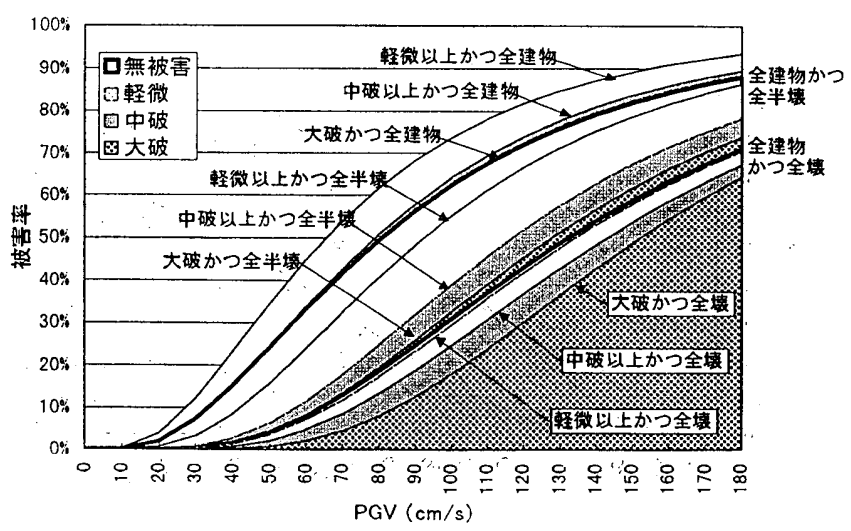

図 15 建物被害推定式における芦屋市判定の内訳
および標準偏差（〕）を示す．図 15は芦屋市の各判定（全壊，半壊， その他）ごとに震特委員会でどのように判定されたかの条件付被害 率を建物被害推定式で表したものである. 図 15では, 半壊以上（全 半壊）上全壊の曲線に挟まれた領域が半壊を表し，半壊以上の曲線 よりも上の部分がその他の判定を表している. 全壊と判定されたも のの大半が大破と判定され，半壊と判定されたものの中では地震動 が大きい所ほど大破と判定されたものの比率が大きくなっている. またその他と判定されたものの中では無被害が大きい比率を占めて いるが，地震動が大きくなるにつれ，中破と判定される比率も大き くなっている.

芦屋市による各判定が, 地震動の大きさによって震特委員会にど

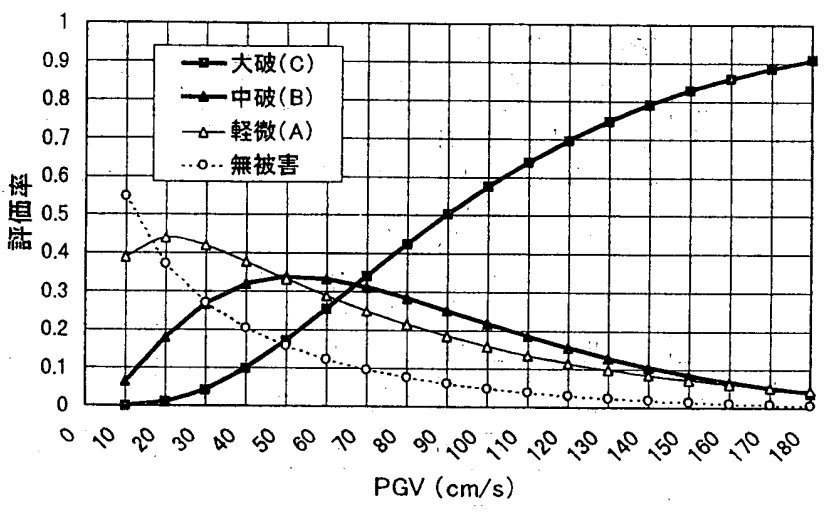

図 16 建物被害判定の評価率（全壊）

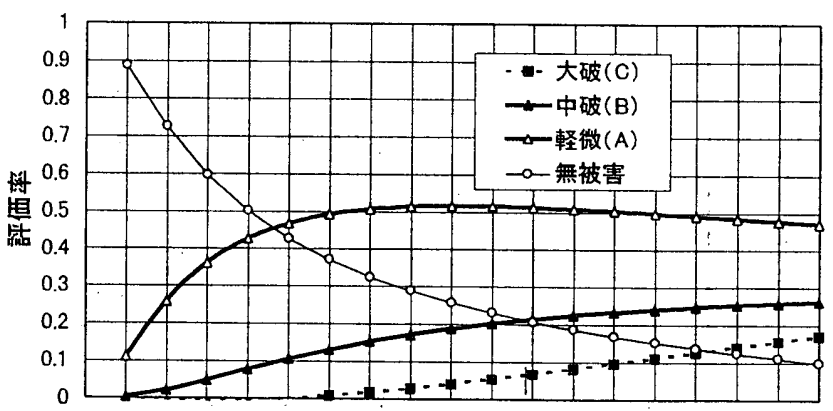

$0,12^{\circ} 3^{\circ} 2^{\circ} 5^{\circ} 6^{\circ}, 1^{\circ} 8^{\circ}, 9^{\circ}, 0^{\circ}, 1^{\circ}, 2^{\circ}, 3^{\circ}, 7^{\circ}, 5^{\circ}, 6^{\circ}, 1^{\circ}, 8^{\circ}$ $P G V(\mathrm{~cm} / \mathrm{s})$

図 17 建物被害判定の評価率（半壊）

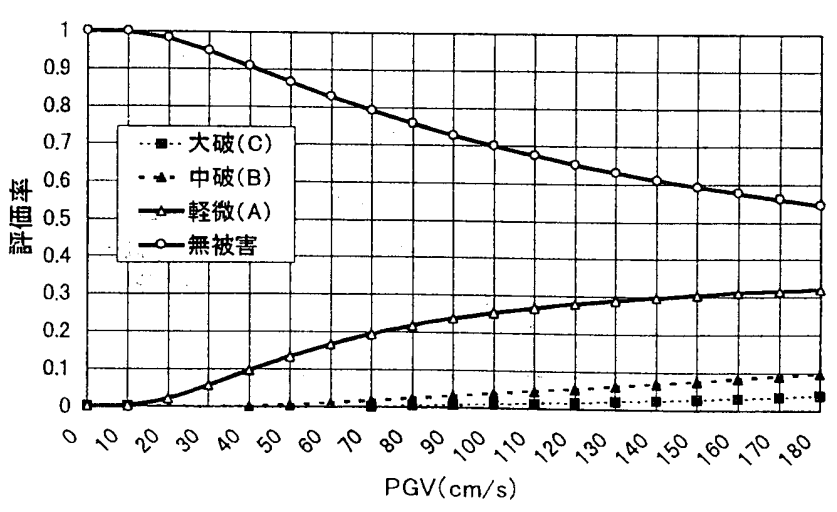

図 18 建物被害判定の評価率（その他） 
のように判定され，どの程度合致したかを評価率という尺度で示し たのが, 図16 (全壊), 図 17 (半壊), 図 18 (その他) である. 評価率は判定ごとの震特委員会の各被害率を芦屋市による各被害率 で除して求めている．また前記した対応レベルに応じて線種を変え ており, Level 1 と Level 2 は太線で示している.

全体として見ると，地震動の強さによって各判定のされ方が違っ ているのがわかる．市によって全壊と判定された建物は地震動の小 さいところでは，大破として判定されている率が低いが，地震動が 大きくなるにつれて評価率も上がり，0.9 まで上がっている．逆に 中破の判定は地震動 $50 \mathrm{~cm} / \mathrm{s}$ のあたりで評価率が 0.3 程であり, 大 破と判定されるものよりも比率が大きいが, $70 \mathrm{~cm} / \mathrm{s}$ あたりで逆転 され，地震動が大きくなるにしたがい，評価率が下がっている．地 震動の小さい地域では一見建物の被害が小さくても，建物内部の被 害は大きいということも考えられる，その場合に外観目視による評 価を行った震特委員会の判定は中破だが，内部評価を含む市の判定 は全壊であるということが起きる．図16のような現象はこのよう な理由によると思われる.

次に半壊の判定では, $50 \mathrm{~cm} / \mathrm{s}$ 付近から $180 \mathrm{~cm} / \mathrm{s}$ まで軽微の評価
率がほぼ 0.5 と安定している. 中破の判定は地震動の増加とともに 緩やかに上昇している. また無被害の判定は $40 \mathrm{~cm} / \mathrm{s}$ 付近で中破と 同程度の評価率であったが, 地震動が大きくなるにつれて 0.1 まで 減少している.

その他の判定の中では, 無被害の評価率が高いが, 地震動が大き くなると 0.5 まで下がり, 逆に軽微の判定は地震動の増加とともに 評価率は 0.3 程度まで上がっている. その他と判定された中での大 破, 中破判定の評価率は, 地震動が大きくなると多少增加している が，それでも 0.1 以下と比較的に小さい.

（4）自治体による全壊率からの評価変換

前節では地震動と被害率の関係から芦屋市と震特委員会の建物被 害判定を比較した。 ただし，ここで用いた地震動分布は震特委員会 による低層戸建住宅の被害率と複数地点の地震観測值から導いた推 定地震動である. したがって, もともとの地霞動そのものが, 震特 委員会の建物被害率と高い相関関係にあると言える.ここではこれ までの結果から媒介変数である地震動を消去し, 自治体全壊率およ び震特委員会大破率から,他の被害率へと変換する方法を提案する.

図 13に被害推定式の比較を示したように，自治体の全壊率がわ

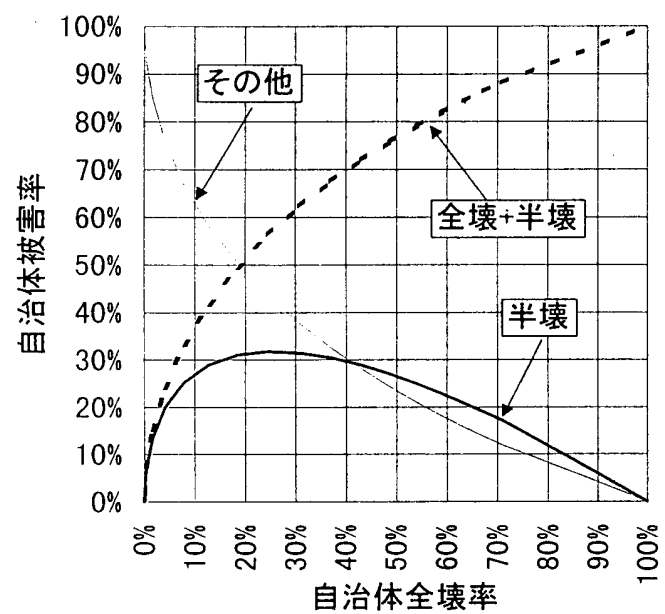

図 19 自治体全壊率から被害率への評価変換

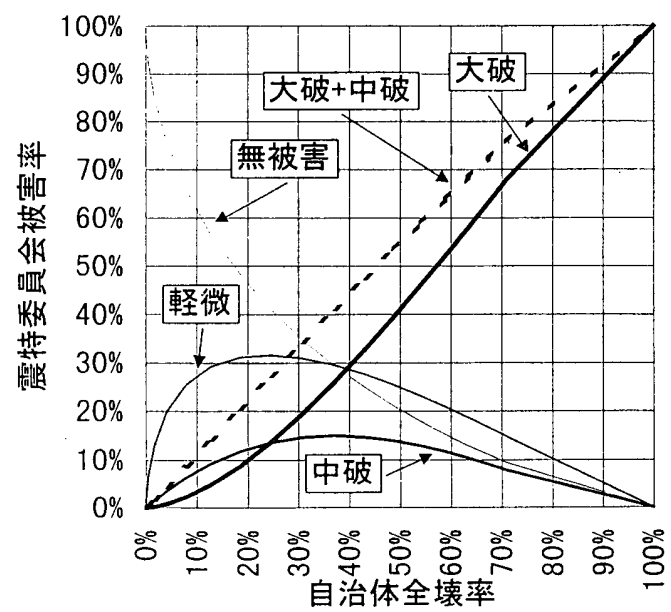

図 20 自治体全壊率から震特委員会被害率への評価変換

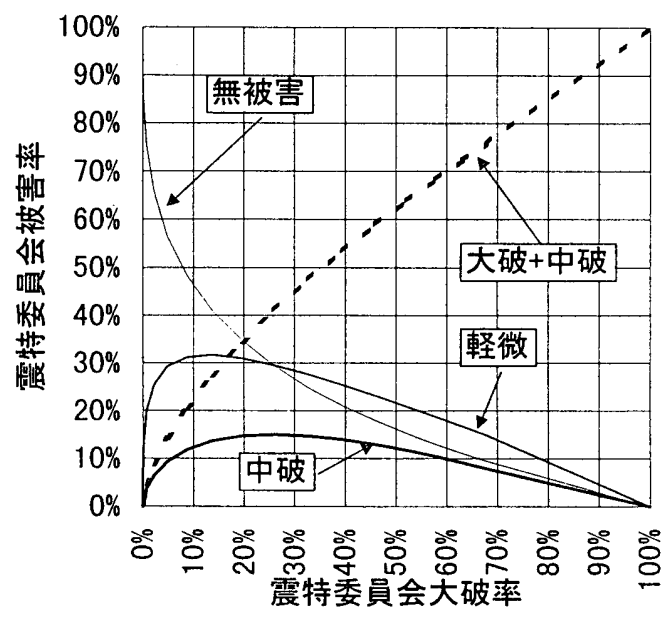

図 21 震特委員会全壊率から被害率への評価変換

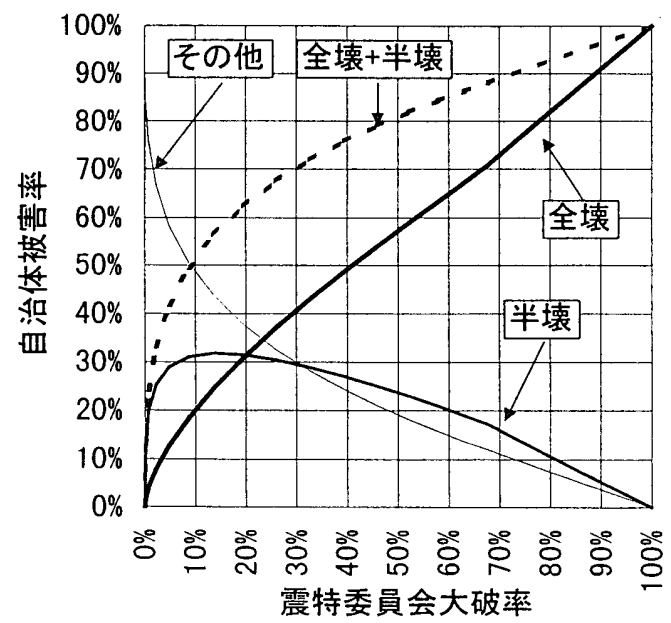

図 22 震特委員会全壊率から自治体被害率への評価変換 
かれば, 地震動がわかり，そこから半壊率，あるいは震特委員会の 被害率 (大破; 中破等) がわかる. 図 19 に自治体の全壊率から他 の被害率へと変換するグラフを示す。どちらも横軸に自治体の全壊 率をとっている，全壊率（地震動）が大きくなるにつれ，被害のな い建物すなわちその他の割合は減り続ける．また半壊は全壊率が 20\%位になるまで增加するが，それ以上の被害になると全壊として 判定されるため, 半壊率は下がっていくのがわかる. 全壊+半壊（全 半壊率) はその他の判定以外のものであるので，その他を表す曲線 と被害率 50\%の線を軸とした線対称の関係になっている.

図 20は自治体の全壊率から，震特委員会の被害率を求めるグラ フである．大破率は全壊率が大きくなるにつれ直線状に増加してい る. 軽微は全壊率が $20 \%$ 程度になるまで急激に增加するが，それ 以降は中破へと変わるため減少していく. 軽微がピークを過ぎたあ たりでそれらの建物は中破へと移行していき，軽微よりも少し高い 40\%付近で中破はピークとなる.また中破以上（大破+中破）は図 6 でも示されたように全壊率とほぼ同じ值をとっている.

図 21 は震特委員会の大破率から震特委員会の他の被害率へと変 換できるようにしたグラフである. 図 20 と同じような傾向がある が，軽微のピークは 10\%あたり，中破のピークは 30\%あたりと， 自治体の全壊率でみるよりも少し低いところに位置している.図 22 は震特委員会の大破率から自治体の被害率への変換グラフである. 図19と比べると, その他, 半壊, 全買+半壊のどの曲線もやや大 破率の低い方向へスライドしたような形になっている。

これらの変換グラフは, 今後の大地震時に実施されるであろう自 治体による建物被害調查を兵庫県南部地震時の被害と比較する場合, あるいは判定基準の異なった兵庫県南部地霞に関する自治体による 詳細な建物被害デー夕を分析する場合に，有効に利用できるものと 思われる. しかし，残念ながら今回分析したデー夕は，村上らの研 究15)のように構造種別, 建築年, 建築規模等の詳細な建物属性を考 虑したものではないため, 建物全体としての平均的な関係であるこ とに注意する必要がある。

\section{4. まとめ}

兵庫県南部地震で被害を受けた芦屋市の約 12,000 棟の建物を対 象として, 自治体と震特委員会による建物被害調査の判定結果を比 較した，その結果，全体としては芦屋市の全壊判定は震特委員会の 中破以上，芦屋市の全半壊判定は震特委員会の軽微な損傷以上にほ ぼ等しいことがわかった．また判定結果と推定地震動（最大地震速 度）との関係を調べた結果, 地震動の大きさが 2 調査による被害判 定結果の違いに影響を与えていることがわかった．地震動の小さい エリア内，そして強固な建物等は倒壊・全壊することが少ない。し かし家具の転倒等により，内部被害は発生しているということが考 えられる，そのような時，建物内部被害の判定項目の有無が，建物 被害調査結果の大きな違いとなって現れてくる．地震動の大きさが 判定結果の違いに影響を与えているのは，このような理由によるも のと考えられる，以上の分析により，自治体による資産的評価を重 視した建物被害調查の判定結果を, 震特委員会の調查に基づく被害 判定へと変換する評価法を提案した. 今後, 大地震が発生した際に 実施されるであろう被災地域の自治体による調査結果を, 判定項目 内容を考慮したうえで，本評価法により変換することにより，兵庫 県南部地震との比較を定量的に行うことが可能になる.

\section{謝辞}

本研究においては, 霞災復興都市づくり特別委員会が実施した建 築物被災度調査結果, 建設省建築研究所がそれを数値デー夕として まとめた結果，芦屋市が調査した建物被害デー夕および資料を利用 させていただいた，記して謝意を表する次第である。

\section{参考文献}

1) 村尾修, 山崎文雄: 兵庫県南部地震における建物被害の自治体による調 査法の比較検討, 日本建築学大会計画系論文集, No.515, pp.187-194, 1999.1.

2) 国土庁：防災白書平成 9 年版, 1997.

3) 震災復興都市づくり特別委員会: 阪神・淡路大震災被害実態緊急調查 被 災度別建物分布状況図集, 1995.

4) 建設省建築研究所 : 平成 7 年兵庫県南部地震被害調查最終報告畫, 1996.

5) 翠川三郎, 藤本一雄 : 墓石の転倒調査から推定した兵庫県南部地震の際 の神戸市およびその周辺での震度分布，日本建築学会構造系論文集，第 490 号, pp.111-118, 1996.12 .

6) 林康裕, 宮䁏㳯一，田村和夫，川瀨博 : 1995 年兵庫県南部地震の低層建 物被害率に基づく最大地動速度の推定，日本建築学会構造系論文集，第 494 믁, pp.59-66, 1997.4 .

7) 芦屋市 : 阪神・淡路大震災 芦屋市の記録'95-'96, 1997

8) 後藤寛子, 山崎文雄, 佐藤修 : 兵庫県南部地震における芦屋市の建築物 被害，地域安全学会論文報告集，No.6，Pp.155-160，1996.11.

9) 杉浦正美, 山崎文雄 : 兵庫県南部地震における宝塚市の被害分析，地域 安全学会論文報告集, No.6, pp.147-154,1996.11.

10) 後藤寛子, 山崎文雄, 若松加寿江, 浅野進一郎 : 兵庫県南部地震におけ る尼崎市の建物被害分析, 第 24 回地震工学研究発表会講演論文集, pp.1233-1236, 1997.7

11）杉浦正美，山崎文雄：兵庫県南部地震における伊丹市の建物被害分析， 第 24 回地震工学研究発表会講演論文集, pp.1257-1260, 1997.7.

12）山口直也, 山崎文雄, 若松加寿江 : 兵庫県南部地震における西宮市の建 物被害分析, 第 24 回地震工学研究発表会講演論文集, pp.1237-1240, 1997.7

13）村尾修，山崎文雄 : 兵庫県南部地震における灘区の建物被害分析，第 24 回地震工学研究発表会論文集, pp.1261-1264, 1997.7 .

14）山口直也，山崎文雄 : 兵庫県南部地震の建物被害による地震動強さの面 分布推定, 土木学会第 53 回年次学術講演会講演概要集, I (B), pp.560$561,1998.10$.

15）村上雅英，田原賢，藤田宜紀，三澤文子 : 阪神・淡路大震災にみる在来 木造都市型住宅の問題点, 日本建築学会構造系論文集, 第 481 号, pp.71-80, 1996.3.

注

1) 主に保険金支払のための「地震保険損害查定調查」，震災復興都市づくり 特別委員会による被災記録のための「被害塞態緊急調查」, 二次災害防止 のための「応急危険度判定調查」, 自治体による減免および義援金補助の ための「家屋被害調査」などが実施された。

2) 芦屋市が実施した建物被害調查では全壊・半壊・一部損壊・その他の 4 区分となっているが，参照した建物被害状況図上では一部損壊・その他の 区分がつけられていなかったため，本研究では芦屋市の判定結果を全壊・ 半壊・その他の3区分として分析した. 